\title{
Vitamin A and Carotenoids
}

\author{
THE ENZYMIC CONVERSION OF $\beta$-CAROTENE INTO RETINAL \\ IN HOG INTESTINAL MUCOSA
}

\author{
By NOEL H. FIDGE, FRANK REES SMITH AND DEWITT S. GOODMAN \\ Department of Medicine, Columbia University College of Physicians and Surgeons, \\ New York, N.Y. 10032, U.S.A.
}

(Received 20 March 1969)

\begin{abstract}
The conversion of $\beta$-carotene into retinal was studied in vitro with enzyme preparations from homogenates of hog intestinal mucosa. The hog mucosal enzyme was purified about 27-fold by precipitation with ammonium sulphate, chromatography on DEAE-Sephadex and gel filtration on Sephadex G-200. The reaction displayed a narrow optimum $\mathrm{pH}$ range (approx. 7.8-8.2). The enzyme was stimulated strongly by the addition of thiols, and was inhibited by thiol inhibitors and by the chelating agents $\alpha \alpha^{\prime}$-bipyridyl and $o$-phenanthroline. The reaction required the addition of an appropriate detergent (or bile salt); maximal activity was obtained by addition of an appropriate combination of detergents and lipid (specifically Tween 40, sodium glycocholate and sphingomyelin). The reaction displayed Michaelis kinetics with $K_{m} 1.3 \times 10^{-6} \mathrm{M}$ and $V_{\max } 1 \cdot 1 \mathrm{nmole}$ of retinal formed/hr. (for $0.7 \mathrm{mg}$. of enzyme protein). The properties of the hog enzyme are similar to those previously reported for a less purified rat enzyme preparation.
\end{abstract}

The conversion of $\beta$-carotene into vitamin $A$ occurs principally in the intestinal mucosa during the absorption of dietary $\beta$-carotene (Glover, Goodwin \& Morton, 1947, 1948; Thompson et al. 1950; Wagner, Wyler, Rindi \& Bernhard, 1960; Huang \& Goodman, 1965; Goodman, Blomstrand, Werner, Huang \& Shiratori, 1966a). This conversion involves the central cleavage of $\beta$-carotene into two molecules of retinal (Goodman \& Huang, 1965; Goodman, Huang \& Shiratori, 1966b) and the reduction of retinal to retinol (Fidge \& Goodman, 1968). The retinol is esterified mainly with longchain fatty acids and absorbed via the lymphatic route in association with lymph chylomicrons (Huang \& Goodman, 1965; Goodman et al. 1966a). A small portion of the retinal may be oxidized in the mucosa to retinoic acid and then absorbed by way of the portal vein (Fidge, Shiratori, Ganguly \& Goodman, 1968).

The conversion of $\beta$-carotene into retinal has been characterized in vitro with enzyme preparations from rat intestinal mucosa (Goodman \& Huang, 1965; Goodman, Huang, Kanai \& Shiratori, 1967). The reaction required molecular oxygen; its mechanism appeared to be that of a dioxygenase reaction (Olson \& Hayaishi, 1965; Goodman et al. $1966 b$ ). The reaction was catalysed by a soluble enzyme, which was purified $2-2 \cdot 5$-fold by precipitation with ammonium sulphate between 20 and
$45 \%$ saturation (Goodman et al. 1967). The enzyme was stimulated by the addition of thiols and was strongly inhibited by thiol inhibitors and by the chelating agents $\alpha \alpha^{\prime}$-bipyridyl and o-phenanthroline. The reaction had optimum $\mathrm{pH}$ approx. 7.7, and required the addition of an appropriate detergent. Maximal activity was obtained by the addition of an appropriate combination of detergents or of detergent and lipid. The detergent-lipid requirement was found to be non-specific. Its role in activating the cleavage reaction was not defined.

We now report studies of the $\beta$-carotene-cleavage reaction conducted with an approximately 27 -foldpurified enzyme preparation from hog intestinal mucosa.

\section{MATERIALS AND METHODS}

Enzyme preparation. Segments of proximal small intestine from hogs were obtained from Swift and Co. (St Paul, Minn., U.S.A.) through the courtesy of The Upjohn Co. (Kalamazoo, Mich., U.S.A.). A 4-6ft. length of proximal small intestine, mainly duodenum, was removed from each hog immediately after slaughter, cut lengthwise, rinsed in iced $0.9 \% \mathrm{NaCl}$ and frozen immediately. The segments arrived in our laboratory frozen, and were thawed gradually. The mucosa was scraped from each segment with a spatula and scrapings were homogenized in $0 \cdot 1 \mathrm{M}$-potassium phos-

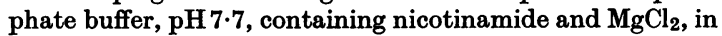
a Potter-Elvehjem homogenizer with a loose-fitting Teflon pestle as described by Goodman et al. (1967); $2.5 \mathrm{ml}$. of 
buffer was used/g. of mucosal scrapings. The homogenate was centrifuged at $2000 \mathrm{~g}$ for $30 \mathrm{~min}$. to provide a supernatant, which usually contained about $17 \mathrm{mg}$. of protein/ml. Further centrifugation of this supernatant at 30000 rev./ min. $(78480 \mathrm{~g})$ for $2 \mathrm{hr}$. in the no. 30 rotor of the Spinco model $\mathrm{L}$ ultracentrifuge resulted in the separation of soluble and particulate fractions. The soluble fraction contained the cleavage-enzyme activity and usually contained about $12.5 \mathrm{mg}$. of protein $/ \mathrm{ml}$. The enzyme was then precipitated, and purified slightly, by the addition of $\left(\mathrm{NH}_{4}\right)_{2} \mathrm{SO}_{4}$ to $55 \%$ saturation. In preliminary experiments it was found that cleavage-enzyme activity was completely recovered in the protein fraction precipitated with $\left(\mathrm{NH}_{4}\right)_{2} \mathrm{SO}_{4}$ between 20 and $45 \%$ saturation. Because the 0-55\%-saturated$\left(\mathrm{NH}_{4}\right)_{2} \mathrm{SO}_{4}$ fraction contained only a little more protein than the $20-45 \%$-saturated-( $\left.\mathrm{NH}_{4}\right)_{2} \mathrm{SO}_{4}$ fraction, for large-scale work only the single precipitation at $55 \%$ saturation was used. The precipitate was stored for several weeks at $-20^{\circ}$ without loss of enzymic activity.

Further purification of the enzyme is described in the legend to Fig. 1. The active pools were combined and chromatographed on a second, smaller, column of DEAESephadex, under conditions similar to those employed for the first chromatography. The enzymically active fractions from this column were then pooled and the protein was subjected to gel filtration on a column of Sephadex G-200, under conditions similar to those described by Kanai, Raz \& Goodman (1968). Protein was eluted from the Sephadex G-200 column in a broad band, from which enzymic activity was recovered just after the mid-portion. The enzymically active fractions were combined and the protein was precipitated with $\left(\mathrm{NH}_{4}\right)_{2} \mathrm{SO}_{4}$ to $60 \%$ saturation.

Enzyme assay. The activity of the carotene-cleavage enzyme was assayed as described by Goodman et al. (1967). Incubations were conducted at $37^{\circ}$ in $25 \mathrm{ml}$. flasks of amber glass with room air as the gas phase. Substrate (labelled $\beta$-carotene) was added dispersed in an aqueous solution of Tween 40 prepared by dissolving the labelled $\beta$-carotene in the desired amount of a solution of $20 \%(v / v)$ Tween 40 in acetone. After evaporation of the acetone with a stream of $\mathrm{N}_{2}$, water was added and the Tween 40 dissolved (and the carotene dispersed) by agitation with a Vortex mixer. The final mixture had a Tween 40 concentration of $10 \mathrm{mg} . / \mathrm{ml}$; $0 \cdot 1 \mathrm{ml}$. of this was added as substrate to each incubation mixture. In preliminary experiments with the hog preparation greater enzymic activity was observed when substrate was added in this way than when it was added in solution in acetone. After incubation the mixtures were extracted, carrier $\beta$-carotene and retinal were added and the extracts were chromatographed on columns of alumina (grade III) as described by Goodman et al. (1967). Retinal was eluted in column fraction 3.

Other procedures. A portion of approximately 12-foldpurified enzyme (purified through the second DEAESephadex column but not subjected to gel filtration) was adjusted to a density of 1.21 by the addition of $\mathrm{NaBr}$ solution of density 1.35. The sample was centrifuged in the SW 39 rotor of the Spinco model L ultracentrifuge for $40 \mathrm{hr}$. at $40000 \mathrm{rev} . / \mathrm{min}$. $(78480 \mathrm{~g})$. After centrifugation the top one-third of the contents of the tube, containing lipoproteins of density less than 1.21, was collected separately from the bottom two-thirds of the contents of the tube. The ' $1 \cdot 21$ top' and '1.21-bottom' fractions were dialysed extensively against 0.01m-potassium phosphate buffer, $\mathrm{pH} 7 \cdot 7$, adjusted to identical volumes and assayed for cleavage-enzyme activity. Phospholipid emulsions were prepared as described by Goodman et al. (1967).

Sources of materials. $\left[15,15^{\prime} \cdot{ }^{3} \mathrm{H}_{2}\right] \beta$-Carotene, a generous gift from Hoffmann-La Roche, Basle, Switzerland, was used in these studies. The labelled $\beta$-carotene was freshly chromatographed on the morning of each experiment as described by Goodman et al. (1967).

\section{RESULTS}

Enzyme purification. Preliminary experiments with hog, sheep and cow mucosal homogenates prepared as described above demonstrated that the hog mucosal preparation actively converted $\beta$. carotene into retinal, whereas neither the cow nor the sheep preparation displayed carotene-cleavage activity under the conditions used for assay.

The partial purification of the cleavage enzyme from the soluble fraction of the hog mucosal homogenate is summarized in Table 1. The protein precipitated with ammonium sulphate at $\mathbf{5 5 \%}$ saturation was three times as active, on a weight basis, as the soluble fraction of the homogenate itself. Further purification was obtained by fractionation of the active ammonium sulphate precipitate on a column of DEAE-Sephadex (see Fig. 1). Rechromatography of the active fractions on a second column of DEAE-Sephadex resulted in a slight additional purification but with a moderate loss of total enzymic activity. Gel filtration on Sephadex G-200 provided an additional 2-3-fold purification (in terms of specific enzyme activity) but a loss of somewhat more than half of the total activity. The elution volume after chromatography on Sephadex G-200, as compared with proteins of known molecular weight, indicated that the hog

\section{Table 1. Partial purification of carotene-cleavage enzyme from hog mucosa}

The preparation was derived from 13 gut segments of total length 65-70ft. The mucosal scrapings weighed $520 \mathrm{~g}$. The volume of the soluble fraction was $705 \mathrm{ml}$. with a protein concentration of $12.5 \mathrm{mg} . / \mathrm{ml}$. Specific enzyme activity is expressed as the percentage yield of retinal $/ \mathrm{mg}$. of protein on assays carried out with protein equivalent to $0 \cdot 7-1 \mathrm{ml}$. of the soluble fraction, assuming linearity between protein added and percentage yield. The final preparation was assayed at double this amount, and linearity was demonstrated with this amount.

\begin{tabular}{lccc}
\multicolumn{1}{c}{ Step } & $\begin{array}{c}\text { Total } \\
\text { protein } \\
(\mathrm{mg} .)\end{array}$ & $\begin{array}{c}\text { Specific } \\
\text { enzyme } \\
\text { activity }\end{array}$ & $\begin{array}{c}\text { Apparent } \\
\text { purification }\end{array}$ \\
Soluble fraction & 8750 & $0 \cdot 88$ & - \\
0-55\%-satd. $\left(\mathrm{NH}_{4}\right)_{2} \mathrm{SO}_{4}$ & 5210 & $2 \cdot 58$ & $\times 3$ \\
DEAE-Sephadex no. 1 & 1570 & $8 \cdot 65$ & $\times 10$ \\
DEAE-Sephadex no. 2 & 830 & $10 \cdot 6$ & $\times 12$ \\
Sephadex G-200 & 147 & $24 \cdot 1$ & $\times 27$
\end{tabular}




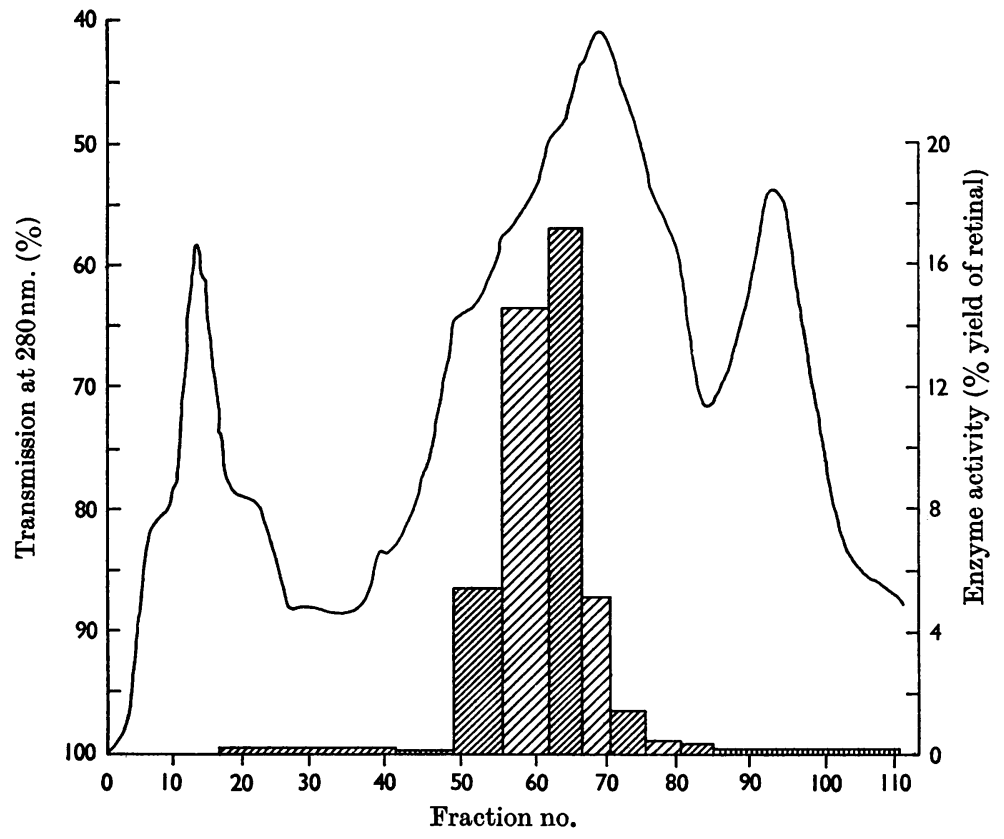

Fig. 1. DEAE-Sephadex chromatography $\left(\right.$ at $\left.4^{\circ}\right)$ of the 0-55\%-saturated-( $\left(\mathrm{NH}_{4}\right)_{2} \mathrm{SO}_{4}$ fraction from hog intestinal mucosa. The $0-55 \%$-saturated- $\left(\mathrm{NH}_{4}\right)_{2} \mathrm{SO}_{4}$ fraction from $150 \mathrm{ml}$. of the soluble fraction of the homogenate was

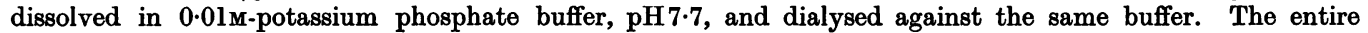
sample $(58 \mathrm{ml}$.) was then applied to a column $(2.7 \mathrm{~cm}$. internal diam. $\times 53 \mathrm{~cm}$; ; bed volume about $300 \mathrm{ml}$.) of $14 \mathrm{~g}$. ofD EAE-Sephadex exhaustively washed with the phosphate buffer. Elution was with 0.01M-phosphate buffer, $\mathrm{pH} 7 \cdot 7$, and a linear gradient of $\mathrm{NaCl}$ from 0 to $1 \cdot 0 \mathrm{M}$. Fractions $(13 \mathrm{ml}$. each) were collected. During chromatography the effluent stream was monitored photometrically at $280 \mathrm{~nm}$. (continuous curve). The collected fractions were pooled as shown and the protein in each pool was precipitated by addition of $\left(\mathrm{NH}_{4}\right)_{2} \mathrm{SO}_{4}$ to $60 \%$ saturation. The precipitates were each dissolved in about $10 \mathrm{ml}$. of $0.01 \mathrm{M}$-potassium phosphate buffer, $\mathrm{pH} 7 \cdot 8$, and dialysed against the same buffer for several hours. Each solution was then assayed for cleavage activity by using portions equivalent to $3 \mathrm{ml}$. of the original soluble fraction of the homogenate. Enzyme assays were carried out with $2 \mathrm{ml}$. incubation mixtures each containing $200 \mu$ moles of potassium phosphate buffer, $\mathrm{pH} 7 \cdot 8,30 \mu$ moles of nicotinamide, $10 \mu$ moles of GSH, $12 \mu$ moles of scdium glycocholate, $400 \mu \mathrm{g}$. of egg lecithin, $0 \cdot 25 \mathrm{mg}$. of $\alpha$-tocopherol added in $25 \mu \mathrm{l}$. of acetone and $0.6 \mu \mathrm{g}$. of $\left[{ }^{3} \mathrm{H}\right] \beta$-carotene as substrate. Incubations were for $1 \mathrm{hr}$.

cleavage enzyme had a probable molecular weight in the range of $100000-200000$; a similar finding was obtained with the rat cleavage enzyme (Goodman et al. 1967). The final extent of purification could not be determined with complete precision because of the apparent increase in total enzyme activity that occurred at the 0-55\%-saturatedammonium sulphate step (Table 1). The apparent overall purification was, however, about 27-fold, when compared with the soluble fraction of the homogenate. Most of the studies reported here were carried out with a preparation purified to this extent.

Other procedures tested for purification of the enzyme included column chromatography on CMSephadex and on hydroxyapatite, batch absorption with alumina $\mathbf{C}_{\gamma}$ gel and preparative polyacrylamide-gel electrophoresis: none provided significant further purification.
Reaction characteristics. The effect of $\mathrm{pH}$ is shown in Fig. 2 : the reaction had a narrow optimum $\mathrm{pH}$ range, about pH 7.8-8.2. The rate of the reaction was constant for approx. 50-60 min. and then decreased progressively, so that the yield of retinal after $120 \mathrm{~min}$. was about 1.5 times that obtained after $60 \mathrm{~min}$. The reaction was directly proportional to enzyme concentration in the range 0-1.1mg. of protein of the purified preparation (equivalent to the range $0-4 \mathrm{ml}$. of the original soluble fraction of the homogenate). Increasing the enzyme concentration above $1 \cdot 1 \mathrm{mg}$. of protein in the $2 \mathrm{ml}$. incubation mixture resulted in relatively smaller further increases in reaction velocity.

Hydrated density. The '1.21-top' (lipoprotein) fraction contained $4 \cdot 2 \%$ of the protein but contained no enzyme activity. The '1.21-bottom' fraction contained over $90 \%$ of the activity of the enzyme 


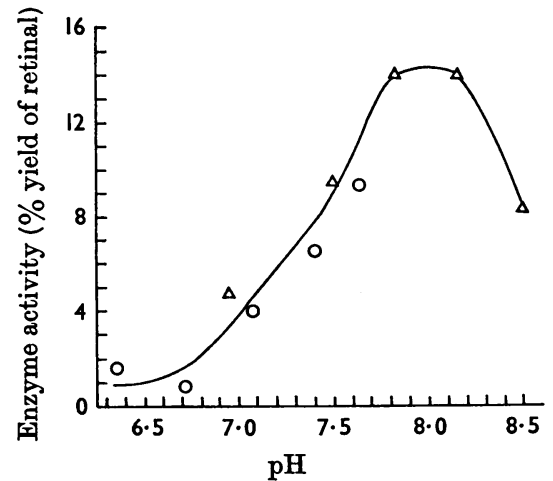

Fig. 2. Effect of $\mathrm{pH}$ on the conversion of $\beta$-carotene into retinal. The assay system was as described in Fig. 1 with $0.8 \mathrm{mg}$. of protein of the hog enzyme preparation (equivalent to $3 \mathrm{ml}$. of the original soluble fraction of the homogenate). Tris-HCl $(\Delta)$ or potassium phosphate $(O)$ buffer $(200 \mu$ moles $)$ was added to give the final $\mathrm{pH}\left(\right.$ at $37^{\circ}$ ) indicated.

Table 2. Effect of addition of bile salt and phospholipids on cleavage-enzyme activity (in the presence of Tween 40)

Each $2 \mathrm{ml}$. incubation mixture contained $0.7 \mathrm{mg}$. of protein of the purified hog enzyme preparation, $200 \mu$ moles of tris-HCl buffer, $\mathrm{pH} 7.9,10 \mu$ moles of GSH, $0.25 \mathrm{mg}$. of $\alpha$ tocopherol (added in $25 \mu \mathrm{l}$. of acetone) and $0 \cdot 6 \mu \mathrm{g}$. of [ $\left.{ }^{3} \mathrm{H}\right] \beta$ carotene. Additions were made in the following amounts: sodium glycocholate (NaGC), $12 \mu$ moles; lecithin (PC), sphinogomyelin (SPH) and phosphatidylserine (PS), $0.5 \mathrm{mg}$. Incubations were for $\mathrm{lhr}$.

Percentage recovery of $3 \mathbf{H}$ in retinal fraction (fraction 3)

\begin{tabular}{lrc}
\cline { 2 - 3 } Addition or omission & Expt. 1 & Expt. 2 \\
None & $12 \cdot 0$ & $14 \cdot 3$ \\
Enzyme omitted & $2 \cdot 3$ & $1 \cdot 5$ \\
NaGC added & $14 \cdot 0$ & $14 \cdot 1$ \\
NaGC+ PC added & $16 \cdot 1$ & $18 \cdot 5$ \\
NaGC+SPH added & $20 \cdot 0$ & $22 \cdot 2$ \\
NaGC+ PS added & $12 \cdot 7$ & - \\
\hline
\end{tabular}

preparation taken. The cleavage enzyme is therefore a protein of hydrated density greater than 1.21. Effects of the addition of bile salt with or without phospholipid. When the substrate was added to the incubations in solution in acetone, there was no conversion of $\beta$-carotene into retinal in the absence of added detergent (or bile salt). When the substrate was added dispersed in an aqueous solution of Tween 40 (Table 2, first line) active conversion of carotene into retinal was observed. Addition of bile salt (sodium glycocholate) slightly stimulated the cleavage reaction in the first experiment, but was without noticeable effect in the second.

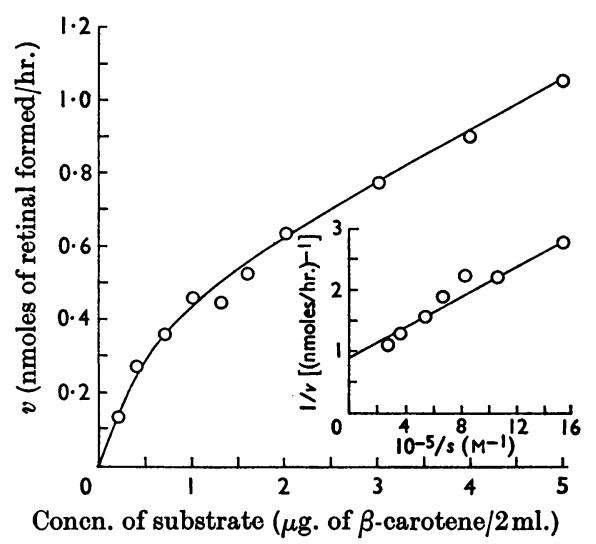

Fig. 3. Effect of substrate concentration on the rate of the cleavage reaction. The assay system was as described in Table 2 with $12 \mu$ moles of sodium glycocholate, $0.5 \mathrm{mg}$. of sphingomyelin and various amounts of substrate (each added with lmg. of Tween 40).

Addition of bile salt plus phosphatidylserine provided no stimulation of the reaction. Addition of bile salt plus lecithin (phosphatidylcholine) resulted in a stimulation of about $30 \%$. Maximal yields were obtained by the addition of bile salt plus sphingomyelin. In subsequent experiments bile salt and sphingomyelin were added to the incubations, to provide optimum conditions for the reaction.

Effects of the addition of synthetic detergents. Addition of sodium glycocholate $(12 \mu$ moles $)$ plus lmg. of either sodium dodecyl sulphate or hexadecyltrimethylammonium bromide slightly inhibited the cleavage reaction. Addition of $2-6 \mathrm{mg}$. of sodium dodecyl sulphate, hexadecyltrimethylammonium bromide or oleyl dihydrogen phosphate, without the addition of bile salt, was strongly inhibitory. Addition of $5 \mathrm{mg}$. of Tween 40 (in addition to the lmg. added along with the substrate) was slightly inhibitory.

Effect of substrate concentration. The reaction rate was directly proportional to the amount of added substrate up to approx. $0.5 \mu \mathrm{g}$. of $\beta$-carotene added to a $2 \mathrm{ml}$. incubation mixture. When $1 / v$ was plotted against $1 / s$ (Fig. 3, inset), a straight line resulted, from which the following values were calculated: $V_{\max } 1 \cdot 1 \mathrm{nmole}$ of retinal formed/hr. (for $0.7 \mathrm{mg}$. of enzyme protein); $K_{m} 1.3 \times 10^{-6} \mathrm{M}$. It should be noted that the $K_{m}$ represents only an apparent value for the Michaelis constant, since $\beta$-carotene is an insoluble substrate that was added to the incubation mixture dispersed in a solution of Tween 40 .

Effects of other additions. Omission of GSH from the usual reaction mixture resulted in a greatly diminished yield of retinal (about one-quarter of that obtained with GSH) (Table 3). Mercapto- 
Table 3. Effects of addition of thiols, thiol inhibitors and chelating agents on cleavage-enzyme activity

The $2 \mathrm{ml}$. incubation mixtures were identical with those of Fig. 3, except that each flask contained $1 \cdot 2 \mathrm{mg}$. of protein and $0 \cdot 6 \mu \mathrm{g}$. of $\left[{ }^{3} \mathrm{H}\right] \beta$-carotene, and that $\mathrm{GSH}$ was omitted from the basal reaction mixture. Percentage yield of retinal was calculated as the percentage of ${ }^{3} \mathrm{H}$ recovered in fractions 3 minus the corresponding value for the control flask without enzyme.

\begin{tabular}{lc}
\multicolumn{1}{c}{ Addition ( $\mu$ moles) } & $\begin{array}{c}\text { Percentage yield } \\
\text { of retinal }\end{array}$ \\
None & $4 \cdot 7$ \\
None & $5 \cdot 9$ \\
GSH (5) & $21 \cdot 1$ \\
GSH (10) & $23 \cdot 1$ \\
Mercaptoethanol (5) & $25 \cdot 3$ \\
Mercaptoethanol (10) & $21 \cdot 0$ \\
$N$-Ethylmaleimide $(0 \cdot 75)$ & $1 \cdot 6$ \\
$N$-Ethylmaleimide $(2 \cdot 5)$ & $0 \cdot 6$ \\
GSH (10)+ EDTA (40) & $22 \cdot 1$ \\
GSH (10)+ $\alpha \alpha^{\prime}$-bipyridyl (1) & $16 \cdot 6$ \\
GSH (10)+ $\alpha \alpha^{\prime}$-bipyridyl (5) & $7 \cdot 7$ \\
GSH (10)+o-phenanthroline $(0 \cdot 3)$ & $8 \cdot 6$ \\
GSH (10)+o-phenanthroline $(1)$ & $11 \cdot 1$ \\
& \\
\hline
\end{tabular}

ethanol was equally effective as was GSH. The reaction was almost completely inhibited by the thiol inhibitor $N$-ethylmaleimide. Addition of EDTA had no effect on the cleavage reaction. In contrast, $\alpha \alpha^{\prime}$-bipyridyl and $o$-phenanthroline sig. nificantly inhibited the reaction (see Table 3 ).

\section{DISCUSSION}

The study was undertaken to compare the previously reported properties of the rat mucosal cleavage enzyme (Goodman et al. 1967) with those of a more purified enzyme preparation from a different species. A preparation of hog mucosal cleavage enzyme was obtained that was an order of magnitude more purified than the previously studied rat enzyme preparation. The properties of the more purified hog enzyme preparation were similar to those of the rat cleavage enzyme. Both enzymes were soluble proteins with molecular weights in the range 100000-200000; both displayed a narrow optimum $\mathrm{pH}$ range at approx. $\mathrm{pH} 8$, with maximal activity in the range $\mathrm{pH} \mathrm{7 \cdot 8-8.2}$ for the hog enzyme

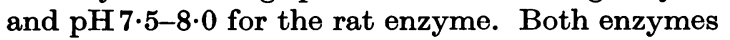
were stimulated by the addition of thiols and inhibited strongly by thiol inhibitors. Both enzymes were inhibited by the chelating agents $\alpha \alpha^{\prime}$-bipyridyl and $o$-phenanthroline but minimally or not at all inhibited by EDTA. These findings suggest the involvement of one or more thiol groups and of a metal ion (perhaps $\mathrm{Fe}^{2+}$ ). In addition, the hog cleavage enzyme was inactive in the absence of any added detergent or bile salt and required the addition of an appropriate combination of detergents and lipid for maximal activity. A similar requirement was observed with the rat enzyme preparation.

Despite these qualitative similarities, quantitative differences were seen in the properties of the two enzymes. The hog enzyme preparation was much more sensitive than the rat enzyme preparation to the omission of thiols from the incubation mixture. On the other hand, the hog enzyme was considerably less sensitive to the inhibitory effects of the chelating agents studied. Maximal stimulation of the hog enzyme was obtained by the addition of sphingomyelin (plus bile salt and Tween 40) to the reaction mixture; in contrast the rat enzyme was stimulated slightly more effectively by egg lecithin than by sphingomyelin (Goodman et al. 1967). The hog enzyme was uniformly inhibited by the synthetic detergents tested, whereas the rat enzyme was effectively stimulated by several synthetic detergents (particularly sodium dodecyl sulphate). As studied in vitro, the hog enzyme preparation displayed Michaelis kinetics with an apparent $K_{m} 1 \cdot 3 \times 10^{-6} \mathrm{M}$ and $V_{\max }$. $1 \cdot 1$ nmole of retinal formed $/ \mathrm{hr}$. (for $0.7 \mathrm{mg}$. of protein of the purified preparation). The value of the $K_{m}$ for the hog enzyme is about one-half that found for the rat enzyme; the value of the $V_{\max }$. for the hog enzyme is, however, several-fold less than that of the rat enzyme. These findings suggest that the hog enzyme binds the substrate a little more tightly than does the rat enzyme, but is less active in catalysing the cleavage of carotene into retinal.

The results fail to provide further insight into the role played by the detergent-lipid combination in stimulating the cleavage reaction. The possible mechanisms by which these additions might stimulate the cleavage reaction have been discussed by Goodman et al. (1967). The properties of the hog and the rat enzyme preparations suggest that the two enzymes are similar with regard to the detailed structure of their active centres and with regard to the mechanism whereby they catalyse the conversion of $\beta$-carotene into retinal. Further understandings of this reaction will probably require much more highly purified cleavage enzyme.

We are grateful to Miss Elizabeth Miller for expert assistance, to Hoffmann-La Roche, Basle, Switzerland, for the generous gift of $\left[15,15^{\prime}-{ }^{3} \mathrm{H}_{2}\right] \beta$-carotene and to The Upjohn Co. for providing us with the tissue used for these studies. This work was supported by Research Grant AM-05968 from the National Institutes of Health (Bethesda, Md.) and by aid from The Upjohn Co. N.H.F. was an Overseas Research Fellow of the Life Insurance Medical Research Fund of Australia and New Zealand during this work. F.R.S. is a Trainee in Metabolism under Grant TI-AM05397 from the National Institutes of Health. D.S.G. is a Career Scientist of the Health Research Council of the City 
of New York under Contract I-399. This is Paper no. 10 in the series 'Vitamin A and Carotenoids' (Paper no. 9: Fidge \& Goodman, 1968).

\section{REFERENCES}

Fidge, N. H. \& Goodman, DeW. S. (1968). J. biol. Chem. 243, 4372.

Fidge, N. H., Shiratori, T., Ganguly, J. \& Goodman, DeW. S. (1968). J. Lipid Res. 9, 103.

Glover, J., Goodwin, T. W. \& Morton, R. A. (1947). Biochem. J. 41, xlv.

Glover, J., Goodwin, T. W. \& Morton, R. A. (1948). Biochem.J. 43, 512.

Goodman, DeW. S., Blomstrand, R., Werner, B., Huang, H. S. \& Shiratori, T. (1966a). J. clin. Invest. 45, 1615.
Goodman; DeW. S. \& Huang, H. S. (1965). Science, 149, 879.

Goodman, DeW. S., Huang, H. S., Kanai, M. \& Shiratori, T. (1967). J. biol. Chem. 242, 3543.

Goodman, DeW. S., Huang, H. S. \& Shiratori, T. (1966b). J. biol. Chem. 241, 1929.

Huang, H. S. \& Goodman, DeW. S. (1965). J. biol. chem. $240,2839$.

Kanai, M., Raz, A. \& Goodman, DeW. S. (1968). J. clin. Invest. 47, 2025.

Olson, J. A. \& Hayaishi, O. (1965). Proc. Nat. Acad. Sci., Wash., 54, 1364.

Thompson, S. Y., Braude, R., Coates, M. E., Cowie, A. T., Ganguly, J. \& Kon, S. K. (1950). Brit. J. Nutr. 4, 398.

Wagner, H., Wyler, F., Rindi, G. \& Bernhard, K. (1960). Helv. physiol. pharmacol. Acta, 18, 438. 